\title{
The dopaminergic response in multiple system atrophy
}

\author{
Andrew J Hughes, Carlo Colosimo, Birgit Kleedorfer, Susan E Daniel, Andrew J Lees
}

\begin{abstract}
Fifteen of 23 pathologically confirmed cases of multiple system atrophy (MSA) showed some initial response to levodopa and eight of these remained at least partially responsive at the time of death. Eleven developed motor oscillations, and drug-induced dyskinesias, often involving the face and jaw, were also seen in 11 cases. Acute levodopa and apomorphine challenges were administered to 11 patients with clinical MSA who were considered levodopa responsive. A short duration relatively small amplitude response with associated dyskinesias occurred in six and a further three developed dyskinesias without any motor response. Following levodopa withdrawal, a delayed deterioration occurred after three to six days in six patients, five of whom had shown no short duration motor response to the acute challenges. The occurrence of levodopa-induced dyskinesias without a concomitant motor response and delayed deterioration several days after levodopa withdrawal may be more typical of patients with MSA than Parkinson's disease.
\end{abstract}

(F Neurol Neurosurg Psychiatry 1992;55:1009-1013)

A marked long term response to levodopa is characteristic of Parkinson's disease (PD) ${ }^{1}$ and patients with a Parkinson's syndrome who do not respond at all are usually found not to have Lewy body pathology at necropsy. Other Parkinsonian syndromes can also sometimes respond, ${ }^{2-5}$ although usually transiently and often not to the same degree. ${ }^{4}$ Occasional cases with histologically proven PD have also been described which show no apparent response to an adequate trial of levodopa. ${ }^{3}$ Multiple system atrophy (MSA) is commonly misdiagnosed as $\mathrm{PD},{ }^{26}$ although the response to levodopa has generally been considered to be poor. Just how often benefit to levodopa is found in MSA is unclear, and few studies have addressed the nature of this response compared with cases of PD. Clinically descriptive studies of MSA sometimes lack histological confirmation, ${ }^{5}$ and unfortunately many cases with proven MSA at necropsy have not been assessed completely with respect to dopaminergic response during life. $^{2}$

To assess these issues further we studied the motor response to single challenges of levodopa and apomorphine, or to the withdrawal of levodopa, in 11 patients with clinical MSA who showed some previous dopaminergic response. We also reviewed the levodopa response in 23 cases of histologically proven MSA from the United Kingdom Parkinson's Disease Society brain bank (PDSBB).

\section{Patients and Methods}

Clinical studies

Eleven patients ( 7 female, 4 male) with clinical features suggestive of MSA who on review of their case notes had an unequivocal history of levodopa responsiveness were selected for study. The mean age of onset of symptoms was 55 years (39-67) and the mean disease duration 8 years $(4-12)$. The clinical features of the cases are summarised in the table. Patients were classified as having clinical MSA according to criteria modified from Quinn. ${ }^{7}$ All had a Parkinsonian syndrome, according to conventional criteria, ${ }^{8}$ accompanied by at least two of the following; evidence on formal testing of autonomic dysfunction, clinical signs of pyramidal tract involvement in the absence of an alternative cause, cerebellar signs without another explanation, or evidence on CT or MRI of unequivocal cerebellar or brain stem atrophy.

Patients were admitted to hospital for testing, which was carried out in the early morning, after an overnight fast, with anti-Parkinsonian medication withheld for 12 hours. All patients received a single oral dose of levodopa/carbidopa $(250 \mathrm{mg} / 25 \mathrm{mg}$, Sinemet 275). In eight patients an apomorphine test was performed on another day under the same conditions, following administration of the peripheral dopamine receptor antagonist, domperidone ( $20 \mathrm{mg}$ three times a day), for 48 hours. These patients were given subcutaneous apomorphine in $1.5,3.0$, and $4.5 \mathrm{mg}$ doses subcutaneously at 30 minute intervals until either a clear motor response was recorded, dose limiting side effects occurred, or the maximum dose was reached. Motor performance was assessed at baseline and at 30 minute intervals after the levodopa challenge and at 15 minute intervals after each dose of subcutaneous apomorphine. Motor response was assessed by unilateral hand tapping on two digital counters mounted $20 \mathrm{~cm}$ apart, time taken to walk 20 meters, and clinical assessments of tremor and dyskinesia according to a four-point scale $(0=$ nil, $1=$ mild, $2=$ moderate, 3 = severe). A modified Webster disability score ${ }^{9}$ was recorded at baseline and at the time of peak improvement. Criteria for a positive response were; $>15 \%$ increase in 
Table Clinical features and initial response to levodopa in 11 cases of clinical multiple system atrophy

\begin{tabular}{|c|c|c|c|c|c|c|c|c|c|}
\hline \multirow[b]{2}{*}{ Case } & \multirow[b]{2}{*}{ Age/sex } & \multirow{2}{*}{$\begin{array}{l}\text { Duration of } \\
\text { symptoms } \\
\text { (years) }\end{array}$} & \multirow{2}{*}{$\begin{array}{l}\text { Initial symptoms } \\
\text { (within first year) }\end{array}$} & \multicolumn{4}{|c|}{ Clinical features of $M S A$} & \multirow[b]{2}{*}{ Investigations } & \multirow[b]{2}{*}{ Early response to levodopa } \\
\hline & & & & $\overline{\text { Autonomic }}$ & Pyramidal & Cerebellar & $\overline{\text { Bulbar }}$ & & \\
\hline 1 & 55/female & 5 & $\begin{array}{l}\text { Right arms stiffness, } \\
\text { slowness, and loss of } \\
\text { arm swing }\end{array}$ & ++ & + & - & + & $\begin{array}{l}\text { Autonomic failure } \\
\text { Cerebellar and brain } \\
\text { stem atrophy on } \\
\text { C/T } \\
\text { Neurogenic sphincter } \\
\text { EMG }\end{array}$ & $\begin{array}{l}\text { Moderate initial response; } \\
\text { AlMs by } 4 \text { years of } \\
\text { treatment }\end{array}$ \\
\hline 2 & $58 /$ female & 7 & $\begin{array}{l}\text { Shuffling gait, left sided } \\
\text { bradykinesia and rigidity }\end{array}$ & + & + & - & + & $\begin{array}{l}\text { Cerebellar \& brain } \\
\text { stem atrophy on } \mathrm{C} / \mathrm{T}\end{array}$ & $\begin{array}{l}\text { Moderate initial response; } \\
\text { AIMs by } 2 \text { years of treat- } \\
\text { ment }\end{array}$ \\
\hline 3 & $56 /$ male & 10 & $\begin{array}{l}\text { Impotence, incontinence } \\
\text { Left sided tremor and } \\
\text { bradykinesia, falls }\end{array}$ & ++ & ++ & - & ++ & $\begin{array}{l}\text { Autonomic failure } \\
\text { Cerebellar and brain } \\
\text { stem atrophy on } C / T \\
\text { Neurogenic sphinchter } \\
\text { EMG }\end{array}$ & $\begin{array}{l}\text { Good initial response; wear- } \\
\text { ing "off" effect marked } \\
\text { AIMs by } 2 \text { years of treat- } \\
\text { r ment. Reduced motor per- } \\
\text { formance and AIMs: with } \\
\text { reduction of levodopa }\end{array}$ \\
\hline 4 & $58 /$ male & 8 & $\begin{array}{l}\text { Incontinence, left sided } \\
\text { bradykinesia, gait distur- } \\
\text { bance }\end{array}$ & ++ & ++ & - & ++ & $\begin{array}{l}\text { Autonomic failure } \\
\text { Cerebrellar and brain } \\
\text { stem atrophy on } \mathrm{C} / \mathrm{T} \\
\text { Neurogenic sphincter } \\
\text { EMG }\end{array}$ & $\begin{array}{l}\text { Moderate initial response to } \\
\text { levodopa. AIMs and "wear- } \\
\text { ing off" effect after } 2 \text { years of } \\
\text { treatment. }\end{array}$ \\
\hline 5 & $48 /$ male & 10 & $\begin{array}{l}\text { Bilateral bradykinesia } \\
\text { and rigidity, postural hy- } \\
\text { potension, impotence }\end{array}$ & ++ & ++ & - & + & Autonomic failure & $\begin{array}{l}\text { Good initial response; AIMs } \\
\text { and motor fluctuations by } 1 \\
\text { year of treatment. }\end{array}$ \\
\hline 6 & $36 /$ female $^{\star}$ & 5 & $\begin{array}{l}\text { Left sided rigidity and } \\
\text { tremor, urinary urgency }\end{array}$ & + & ++ & - & + & $\begin{array}{l}\text { Cerebellular and brain } \\
\text { stem atrophy on } C / T \\
\text { Neurogenic sphincter } \\
\text { EMG }\end{array}$ & $\begin{array}{l}\text { Moderate initial response; } \\
\text { AlMs and motor fluctu- } \\
\text { ations by } 1 \text { year of treat- } \\
\text { ment. }\end{array}$ \\
\hline 7 & $67 /$ female & 7 & $\begin{array}{l}\text { Right upper limb tremor } \\
\text { and bradykinesia }\end{array}$ & ++ & ++ & - & + & $\begin{array}{l}\text { Autonomic failure } \\
\text { Cerebellar and brain } \\
\text { stem atrophy on } C / T \\
\text { Neurogenic sphincter } \\
\text { EMG }\end{array}$ & $\begin{array}{l}\text { Moderate initial response; } \\
\text { some myoclonus? dyskinesia } \\
\text { after } 5 \text { years of treatment. }\end{array}$ \\
\hline 8 & 48/female & 12 & $\begin{array}{l}\text { Left upper limb rigidity } \\
\text { and bradykinesia, gait } \\
\text { disturbance }\end{array}$ & ++ & ++ & + & ++ & Autonomic failure & $\begin{array}{l}\text { Good initial response; AIMs } \\
\text { and motor fluctuations by } 3 \\
\text { years of treatment. }\end{array}$ \\
\hline 9 & $69 /$ male & 10 & $\begin{array}{l}\text { Upper limb tremor and } \\
\text { rigidity, impotence and } \\
\text { postural hypotension }\end{array}$ & ++ & + & - & - & $\begin{array}{l}\text { Autonomic failure. } \\
\text { Cerebellar and brain } \\
\text { stem atrophy on } C / T\end{array}$ & $\begin{array}{l}\text { Moderate initial response; } \\
\text { no AIMs. }\end{array}$ \\
\hline 10 & 56/female & 4 & $\begin{array}{l}\text { Shuffling gait, general- } \\
\text { ized bradykinesia, dysar- } \\
\text { thria }\end{array}$ & + & + & - & + & $\begin{array}{l}\text { Cerebellar and brain } \\
\text { stem atrophy on } \\
\mathrm{C} / \mathrm{T}\end{array}$ & $\begin{array}{l}\text { Moderate initial response; } \\
\text { AIMS after } 1 \text { year of treat- } \\
\text { ment. }\end{array}$ \\
\hline 11 & $51 /$ female ${ }^{\star}$ & 10 & $\begin{array}{l}\text { Right upper limb rigidi- } \\
\text { ty and bradykinesia, gait } \\
\text { disturbance }\end{array}$ & + & - & - & ++ & Autonomic failure & $\begin{array}{l}\text { Good initial response, fluc- } \\
\text { tuations after } 2 \text { years and } \\
\text { AIMs, mainly dystonic, by } 4 \\
\text { years of treatment. }\end{array}$ \\
\hline
\end{tabular}

AIMs = Abnormal involuntary movements.

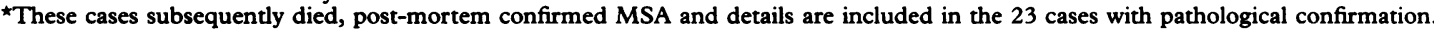

\$This case did not satisfy our clinical criteria but is included as there was pathological confirmation of MSA.

$-=$ no features, $+=$ mild features, $++=$ marked clinical features.

tapping score, $>25 \%$ improvement in walking time, improvement in tremor score of at least 2 points, or improvement in the Webster score of three or more.

Patients who showed no motor response to the acute dopaminergic challenges or who were not disabled after 12 hours without levodopa, despite having shown a short duration response, were withdrawn from all levodopa and followed for later deterioration. As soon as patients demonstrated further motor decline, so that they were not unacceptably disabled or distressed, they were restarted on levodopa and the timing of subsequent improvement noted, according to measurements of motor performance performed each 3 hours during daylight hours.

\section{Pathologically proven cases}

The case histories of 23 cases with histologically proven MSA collected over a 5 year period at the PDSBB were reviewed. Halfbrains fixed in $10 \%$ neutral formalin were available for examination using standard neuropathological methods. The diagnosis of MSA was made using accepted neuropathological criteria, ${ }^{210}$ with all cases showing striatonigral involvement combined in most with some degeree of olivopontocerebellar damage.
Seventy four per cent (17/23) of cases were registered brain bank donors and had been prospectively assessed annually by neurologists using a standard proforma assessment sheet. Hospital, neurologist and general practice case notes were reviewed to collect clinical information where not available from the annual assessment sheets. Clinical features collected included; age at disease onset, duration of disease to death, nature of initial and late features of disease, and an estimate of the initial response to levodopa according to; nil to poor ( $<30 \%$ response), moderate (30 to $50 \%$ response), good (50 to $70 \%$ response), or excellent ( $>70 \%$ response). Where information was available, the persistence of a response to levodopa, and the development of druginduced fluctuations and dyskinesias, were also recorded.

\section{Results}

Clinical studies

Of the 11 patients studied the initial motor response with levodopa was classified as moderate in seven and good in four. Ten had developed dyskinesias thought to be levodopa induced; in 6 these were predominantly choreic in nature, in 3 they were dystonic while in one they appeared more myoclonic. Dyski- 
nesias began a mean of 2.5 years after levodopa introduction, were generalised including the facial musculature in 7 cases, involved only one limb in 2 and were isolated to the face in one. Six patients described motor fluctuations.

Following the acute challenge of levodopa six patients had a definite motor response, in all associated with dyskinesias. Five of these had described motor fluctuations. The mean improvement in Webster score was $\mathbf{4 . 4}$, in
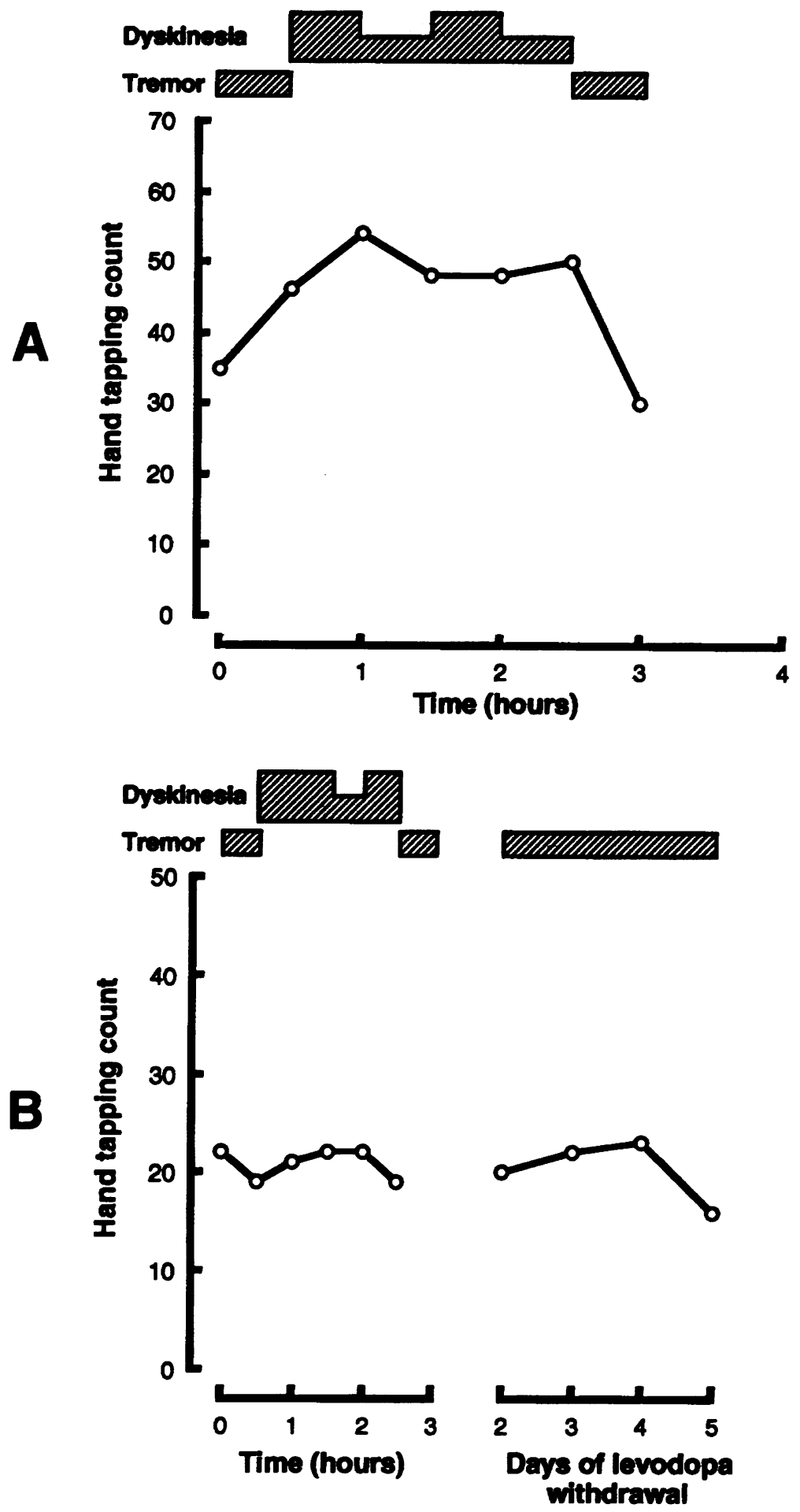

Figure Response to oral levodopa challenge, (a) Case 6. Short duration improvement in tapping score with development of dyskinesias. Webster disability score improved from 14 to 10. Prolonged withdrawal of levodopa not undertaken. (b) Case 1. Dyskinesias without a short duration motor response. Webster disability score was unchanged at 22. After 5 days withdrawal of levodopa Webster score increased to 28 with marked rigidity, immobility, dysphonia and dysphagia. Improvement occurred over 24 hours after starting levodopa. tapping score was 8 per 30 seconds, and in tremor score was one. Three further cases developed dyskinesia with no demonstrable motor response, and two cases showed no dyskinesia or short duration motor response. Seven of the eight patients who received apomorphine showed the same type and magnitude of response as that which occurred with levodopa, the other developed nausea, vomiting and postural hypotension making assessment of the response impossible.

After acute testing, five patients without a short term motor response and two with an acceptable level of mobility after 12 hours without treatment, despite having a short term response, were withdrawn from levodopa. All seven patients subsequently deteriorated; one who also had a short duration motor response, deteriorated to an unacceptable level after 24 hours, while three patients took three days, and three took five to six days to show decline. In five cases deterioration included gradual decline in bulbar function, with progressive dysphonia, difficulty with mastication and dysphagia. Three patients became almost completely aphonic and aphagic. With the reintroduction of levodopa six responded with a return to approximately their previous level of motor performance over 24 hours, three within 12 hours, while one took several days. The figure shows sample responses from two patients; one with a short duration motor response accompanied by dyskinesias who did not have a prolonged period of levodopa withdrawal, and another from a patient with dyskinesias without a short duration motor response following the levodopa challenge, who deteriorated over several days without levodopa.

Pathologically proven cases

The mean age of disease onset was $57 \cdot 1$ years (34-76), mean disease duration 6.8 years (2-11) and mean age at death 63.9 years (39-80); 14 patients were female and nine were male. An akinetic/rigid onset was most common and occurred in isolation in 14 patients, and with some associated tremor in a further five. Within 1 year of disease onset seven cases developed autonomic features, nine suffered from falls, three had pyramidal tract signs and one had cerebellar features. The initial diagnosis was PD in 17, MSA in four and two were labelled as atypical Parkinsonism.

An estimate of the initial response was available in 20 of the 21 patients who were treated with an adequate trial of levodopa. This was classed as nil to poor in five, moderate in six, good in eight, and excellent in one. In six cases a definite response to levodopa continued until death, although this was often of only minor functional value, while in two further cases there was thought to be a persisting slight response. The mean dose of levodopa at death was $580 \mathrm{mg}$ per day. Dyskinesias in response to levodopa were recorded in 11 cases, after a mean of 3.2 years of treatment. Dyskinesias involved facial musculature alone in five cases, in combination with other body parts in a 
further five, and in one case they were confined to the right upper limb. Motor fluctuations of either the "wearing off" or random "on-off" types were also recorded in 11 cases beginning a mean of 2.8 years after starting treatment with levodopa. Eight cases had both fluctuations and dyskinesias and six had either feature in isolation. The predominant disease pattern was akinetic/rigid in eight, mixed tremor/akinetic/rigid in 13 and almost no Parkinonism in two. Over the full course of the illness 16 cases developed autonomic dysfunction, which was documented by formal testing in 10; 12 had pyramidal tract involvement, and cerebellar signs were present in six. At death 13 cases carried the clinical diagnosis of MSA, one was described as having atypical Parkinsonism, and nine were still thought to have had PD.

\section{Discussion}

MSA is a clinicopathological term encompassing striatonigral degeneration, olivopontocerebellar atrophy and some cases of autonomic failure with or without additional neurological signs. ${ }^{710}$ Early in the course of the disease patients can be separated into clinical subgroups, but with disease progression considerable overlap occurs. ${ }^{71}$ At initial presentation there may be extrapyramidal features in isolation and even at death it is one of the must common conditions mistaken for PD. ${ }^{6}$ Besides autonomic, pyramidal, and cerebellar features, clinical pointers to MSA include early instability and falls, relative infrequency of rest tremor, rapid progression, severe dysphagia and dysphonia and a poor or non sustained response to levodopa. ${ }^{2411-13}$ This poor response may be due to striatal damage and consequent loss of post-synaptic dopamine receptors. However, $\mathrm{D}_{2}$ receptor labelling with raclopride using positron emission tomography in MSA has not shown a marked reduction in receptor binding. ${ }^{14}$

Although the majority of patients with MSA show at best a short-lived, partial response to levodopa ${ }^{411}$ occasional cases with a response lasting for several years have been described. ${ }^{2}$ In reviewing cases of histologically proven MSA from the literature Lees found that about $30 \%$ had an initial response, ${ }^{4}$ although a sustained response occurred far less often. In a personal clinicopathological series Rajput et al also found that a third of early MSA cases initially had some response. ${ }^{3}$ The frequency of response in most clinical series is higher, ranging up to $80 \%,{ }^{15}$ presumably due to differing criteria for the clinical diagnosis of MSA and the inclusion of varying numbers of cases with PD. This variable response may be due to the relative degree of nigral versus striatal damage. Those with mainly nigral damage, thought to predate striatal involvement, may have a better response than those with damage to the striatum and presumed receptor loss. Fearnley and Lees have supported this hypothesis by the finding that relative preservation of the putamen correlated with levodopa responsiveness. ${ }^{2}$ Although we did not assess the levodopa response in all cases of MSA we were able to locate and confirm a response in 11 of 30 patients whose case notes were reviewed. The criteria we have used for the clinical diagnosis are stringent, but as the final diagnosis of MSA is a pathological one, we acknowledge that some of our cases may turn out to have either PD or another Parkinsonian syndrome. Among our cases of pathologically proven MSA some initial levodopa response was recorded in about $70 \%$ although ony a third were felt to still have some response at death. If we consider only a response of $>$ than $50 \%$ to be significant then only $9 / 21$ responded initially with $6 / 21$ still responsive at death.

We have observed three types of levodopa response in clinical MSA. Firstly, a short duration motor improvement with associated "on" period dyskinesias, similar to that seen in many patients with Parkinson's disease treated with levodopa for several years. Although some patients with PD can have a similar magnitude of response to our cases, it was our impression that the magnitude was smaller and of less functional benefit than is usual in PD. However, the small number of patients involved did not allow a meaningful statistical comparison. A finding rarely seen in PD was the development of levodopa-induced dyskinesias in the absence of a demonstrable short duration motor response. In all of these cases, however, there was an undoubted delayed deterioration on cessation of treatment. Finally, a delayed deterioration of motor status over several days following withdrawal of levodopa occurred in some cases without an observable short term response of any sort. This deterioration often included profound disturbance of bulbar function. In these patients there was a more rapid restoration of motor performance following reintroduction of levodopa.

Levodopa-induced dyskinesias, at least initially restricted to the face and jaw, are well described in MSA, ${ }^{4116^{1-19}}$ and rare cases with facial dyskinesia without therapeutic improvements have also been reported. ${ }^{20}$ In our study we have also found facial dyskinesias to be common, although usually occurring in combination with more generalised dyskinesias. The development of dyskinesias in the absence of a short duration motor response is unusual in PD, and was found in only three of 24 patients studied by Muenter and Tyce. ${ }^{21}$ In our experience of a large number of levodopa challenge tests in patients with clinical PD such a pattern of response was rare, ${ }^{22}$ reinforcing the clinical observation that in PD the development of levodopa-induced dyskinesias is closely linked to the motor response. Our findings in patients with MSA indicate that this may not always be so, and that dyskinesias alone cannot be taken as proof of a short duration motor response. Furthermore, it supports the suggestion that separate pathophysiological mechanisms may underlie dyskinesia and the motor response and that this type of response may even be more typical of MSA than PD. ${ }^{23}$

Motor fluctuations in response to levodopa have been reported previously in MSA. ${ }^{25} \mathrm{As}$ in 
5 of our cases there are also previous reports of a gradual deterioration of motor status following the withdrawal of levodopa in patients with MSA. ${ }^{16}{ }^{18}$ Despite considerable anecdotal literature relating to delayed deterioration in PD following levodopa withdrawal, based on personal studies we consider the predominance of delayed over short duration deterioration to be a very uncommon event. The common pattern is for most deterioration to occur within the first 24 hours, although some additional deterioration may occur after this. Few well documented studies have addressed this issue but Muenter and Tyce found a long duration response in the absence of a short duration response in only four of 24 patients with clinical $P D^{21}$ Many studies from patients undergoing levodopa drug holiday also support a predominant short duration deterioration, especially in those who have been on levodopa therapy for some time. ${ }^{24} 25$ It is also interesting that some patients with clinical PD reported to have a predominance of delayed deterioration were severely disabled after quite a short disease duration, ${ }^{26}$ (four with Hoehn and Yahr stage 4 after mean disease duration of only 4 years), a progression of disease more typical of MSA. A slight response to levodopa which is only obvious on withdrawal of treatment has been reported in up to $40 \%$ of patients with MSA, ${ }^{11}$ also suggesting that this type of response may be more typical of MSA than PD.

Rapid improvement in motor performance after reintroduction of levodopa was commonly reported in the era of levodopa drug holidays. ${ }^{27}$ In fact an increased response, with considerable reduction in the pre-withdrawal level of disability, has also been reported. ${ }^{27} \mathrm{We}$ did not observe an enhanced response to levodopa following reintroduction in our patients, but the rapidity of response suggests a disassociation between rate of deterioration following cessation of treatment and the speed of motor improvement on reintroduction of levodopa.

Our observations have confirmed previous studies suggesting that a response to levodopa with the later development of motor fluctuations and levodopa-induced dyskinesias is not specific to patients with Lewy body pathology. ${ }^{38-30}$ We also conclude that in MSA a response to levodopa occurs more often than is generally believed, depending on duration and stage of illness, although the magnitude and nature of the response can differ from that usually seen in Parkinson's disease.

We thank Miss Siobhan Blankson and Miss Linda Kilford for the histological preparations, Dr Niall Quinn for permission to include one of his patients, and neurologists associated with the UKPDS brain bank for their work assessing donors antemortem. Dr A J Hughes and Dr S E Daniel were funded by the mortem. Dr A Hughes and D' Colosimo was funded by the European Science Foundation.

1 Barbeau A, Roy M. Six year results of treatment with levodopa plus benzerazide in Parkinsons Disease. Neurol ogy 1976;26:399-404.
2 Fearnley JM, Lees AJ. Striatonigral degeneration: a clinicopathological study. Brain 1990;113:1823-42.

3 Rajput AH, Rozdilsky B, Rajput A, Ang L. Levodopa efficacy and pathological basis of Parkinson syndrome. Clin Neuropharmacol 1990;13:553-8.

4 Lees AJ. The treatment of multiple system atrophy: striatonigral degeneration and olivopontocerebellar degeneration. In: Bannister R, ed. Autonomic failure: a textbook of clinical disorders of the autonomic nervous system, 2nd ed. Oxford: Oxford University Press, 1988:596-604.

5 Lang AE, Birnbaum A, Blair RDG, Kierans C. Levodopa dose-related fluctuation in presumed olivopontoceredose-related fluctuation in presumed olivopont
bellar atrophy. Movement Disord 1986;1:93-102.

6 Hughes AJ, Daniel SE, Kilford L, Lees AJ. The accuracy of clinical dignosis of idiopathic Parkinson's disease: a clinicopathological study. F Neurol Neurosurg Psychiatry 1992;55:181-4

7 Quinn N. Multiple system atrophy-the nature of the beast. f Neurol Neurosurg Psychiatry 1989; (special supplement): 78-89.

8 Ward CD, Gibb WR. Research diagnostic criteria for Parkinson's disease. In: Streifler MB, Korczyn AD, Melamed E, Youdim MBH, eds. Adv Neurol, vol 53: Parkinson's disease: anatomy, pathology, and therapy. New Parkinson's disease: anatomy, pathok

9 Kempster PA, Frankel JP, Bovindon M, Webster R, Lees AJ, Stern GM. Levodopa peripheral pharmacokinetics and duration of motor response in Parkinson's disease. $\mathcal{F}$ duration of motor response in Parkinson's
Neurol Neurosurg Psychiatry 1989;52:718-23.

10 Adams RD, Van Bogaert L, Van Der Eecken H. Striatonigral degeneration. $\mathcal{F}$ Neuropathy exp Neurol 1964; 24:584-608.

11 Quinn N. Multiple system atrophy. In: Marsden CD, Fahn S, eds. Movement disorders, vol 3. London: Butterworths, 1991 (in press).

12 Rajput AJ, Kazi KH, Rozdilsky B. Striatonigral degeneration response to levodopa therapy. $\mathcal{f}$ Neurol Sci 1972;16:331-41.

13 Izumi K, Inoue N, Shrabe T, Miyazaki T, Kuroiwa Y. Failed levodopa therapy in striato-nigral degeneration. Lancet $1971 ; \mathbf{i}: 1355$.

14 Ibanez V, Sawle GV, Brooks DJ, et al. The integrity of striatal $\mathrm{D}_{2}$ sites in Parkinson's disease, striatonigral degeneration, and Steele-Richardson-Olszewski syndrome, studied with 11C-raclopride and PET. Neurology 1990;40(suppl 1):443

15 Goetz CG, Tanner CM, Klawans HL. The pharmacology of olivopontocerebellar atrophy. Adv Neurol 1984;41: 143-8.

16 Gosset A, Pellissier F, Delpuech F, Khalil R. Degenerescence striato-nigrique associee a une atrophie olvo-pontocerebelleuse. Rev Neurol 1983:139:125-39.

17 Trotter J, Striato-nigral degeneration. Alzheimer's disease and inflammatory changes. Neurology 1973;23:1211-16.

18 Boudin G, Guillard A, Mikol J, Galle P. Degenerescence striato-nigrique a propos de l'etude clinique, therpeustriato-nigrique a propos de l'etude clinique, therpeu132:137-56.

19 Feve JR, Mussini JM, Mathe JF, Cler JL, Nombalais MF. Degenerescence striato-nigrique-etude clinique et anatomique d'un cas ayant reagi tres favorablement a la L-dopa. Rev neurol 1977;133:271-8.

20 Sharpe JA, Rewcastle NB, Loyd KG, Hornykiewicz O, Hill M, Tasker R. Striato-nigral degeneration response to levodopa therapy with pathological and neurochemical correlation. I Neurol Sci 1973;19:275-86.

21 Muenter MD, Tyce GM. L-dopa therapy of Parkinson's disease: plasma 1-dopa concentration, therapeutic response and side effects. Mayo Clin Proc 1971;46: 231-9.

22 Hughes AJ, Lees AJ, Stern GM. Apomorphine test to predict dopaminergic responsiveness in parkinsonian predict dopaminergic responsive
syndromes. Lancet 1990;336:32-4.

23 Mouradian MM, Heuser IJE, Baronti F, Fabbrini G, Juncos $\mathrm{JL}$, Chase TN. Pathogenesis of dyskinesias in Parkinsons disease. Ann Neurol 1989;25:523-6.

24 Goetz CG, Tanner CM, Nausieda PA. Weekly drug holiday in Parkinson disease. Neurology 1981;31:1460-2.

25 Koller WC. Alternate day levodopa therapy in parkinsonism. Neurology 1982;32:324-6.

26 Ogasahara S, Nishikawa Y, Takahashi M, et al. Dopamine metabolism in the central nervous system after discontinuation of L-dopa therapy in patients with Parkinson's disease. If Neurol Sci 1984;66:151-63.

27 Klawans HL, Goetz CG, Tanner CM, Nausieda PA, Weiner WJ. Levodopa-free ("drug holidays") in the management of parkinsonism. In: Fahn S, Calne DB, Shoulson I, eds. of parkinsonism. In: Fahn S, Calne DB, Shoulson I, eds. Adv Neurol, vol 37: experimental therapeutics of

28 Daniel SD, Lees AJ. Neuropathological features of Alzheimer's disease in non-demented parkinsonian patients. $\mathfrak{f}$ Neurol Neurosurg Psychiatry 1991;54:972-5.

29 Lang AE, Meadows JC, Parkes JD, Marsden CD. Early onset of the "on-off" phenomenon in children with symptomatic parkisonism. I Neurol Neurosurg Psychiatry 1982;45:823-5.

30 Murrow RW, Schweiger GD, Kepes JJ, Koller WC. Parkinsonism due to a basal ganglia lacunar state: clinicopathologic correlation. Neurology 1990;40:897-900. 